\title{
Role of specific IgE to $\beta$-lactoglobulin in the gastrointestinal phenotype of cow's milk allergy
}

\author{
Paloma Poza-Guedes ${ }^{1}$, Yvelise Barrios² ${ }^{2}$ Ruperto González-Pérez ${ }^{1}$, Inmaculada Sánchez-Machín ${ }^{1,3}$, \\ Andres Franco ${ }^{2}$ and Víctor Matheu ${ }^{1 *}$
}

\begin{abstract}
Rationale: The prevalence of many phenotypes of food allergy is increasing. Specific gastrointestinal (GI) phenotype of food allergy (Gl allergy) is also increasing but it is difficult to know the prevalence because of many entities.

Methods and Results: A 1 year retrospective study of pediatric patients complaining exclusively gastrointestinal symptoms after cow's milk consumption and at least one positive specific lgE (slgE) to cow's milk (CM) proteins (CMP) was done $(n=39)$. The most prevalent symptom was abdominal cramps in 35 patients $(90 \%)$, discomfort or abdominal distention in 30 patients (75\%), diarrhea in 10 patients (25\%) and constipation in 5 patients (12\%). IgA anti-transglutaminase antibodies were absent and lactose intolerance was ruled out in all patients. Average of total IgE on this group was $288 \mathrm{UI} / \mathrm{ml}$. slgE against $\beta$-lactoglobulin was the dominant with an average of $4.14 \mathrm{kU} / \mathrm{l}$. slgE to casein (CAS), which is the dominant protein in systemic anaphylaxis was $1.74 \mathrm{kU} / \mathrm{l}$; slgE to a-lactoalbumin, the other whey protein, was $0.83 \mathrm{kU} / \mathrm{l}$ and slgE levels to CM were $0.78 \mathrm{kU} / \mathrm{l}$. The quotient slgE CAS/slgE $\beta$-lactoglobulin in these patients was always lower than 1. Patients experienced an improvement of their symptoms after a CM free diet. An open oral challenge with CM did mimic their initial symptoms in all patients. However, the open oral challenge with dairy products was well tolerated.
\end{abstract}

Conclusions: Patients with a specific phenotype of GI allergy with CM have specific IgE against $\beta$-lactoglobulin, as a dominant slgE. These patients could beneficiate of a diet with dairy products.

Keywords: Cow's milk allergy, Food allergy, Gastrointestinal allergy, Specific IgE, $\beta$-lactoglobulin, Casein, Anaphylaxis, lgE-mediated allergy

\section{Findings}

Food allergy is currently recognized as a rising problem worldwide. Specific gastrointestinal (GI) food allergy (GI allergy) is also increasing [1] although it is difficult to know the real prevalence because some entities may overlap and many unclear mechanisms are probably involved [1-3]. GI Allergy could be classified into three types according to the implication of immunoglobulin $\mathrm{E}$ (IgE) in their pathogenesis, i.e. classical "IgE-mediated entity"; a "combined IgE- and cell-mediated" type and

\footnotetext{
*Correspondence: victor.matheu@gmail.com; victor.matheu@med.lu.se ${ }^{1}$ Consulta de Alergia Infantil, Unidad de Alergología-Norte, Hospital del Tórax/Ofra, CHUNSC, Sta. Cruz de Tenerife 38320, Spain

Full list of author information is available at the end of the article
}

finally, a "cell-mediated/non-IgE-mediated", consistent with several conditions such as food intolerance or food protein-induced enterocolitis syndrome. Interestingly, those patients afflicted with the GI allergy phenotype develop selective gastrointestinal symptoms exclusivelyin contrast to systemic anaphylaxis-hours after the ingestion of offending foods $[1,4]$; they probably belong to the cell-mediated/non-IgE-mediated or combined IgEand cell-mediated food allergy types which are generally diagnosed on the basis of the clinical manifestations [1, 4, 5]. The final pathogenic mechanisms of GI allergy have not been elucidated yet since the diagnostic approaches are not clear and no consensus has been reached either. 


\section{Methods}

We performed a 1-year observational retrospective study of patients with selective GI symptoms-i.e. discomfort, abdominal distention, abdominal cramps, flatulence, nausea, vomiting, constipation or intermittent diarrhea only over 30 min after the intake of a glass of cow's milk. The inclusion criteria also comprise a positive ( $>0.1 \mathrm{kU} / \mathrm{l})$ serum specific IgE (sIgE) to cow's milk proteins (CMP) such as casein (CAS), and the main whey proteins such as $\alpha$-lactoalbumin (ALA) and $\beta$-lactoglobulin (BLG). Those patients with confirmed extra-intestinal-cutaneous, ocular, respiratory and/or cardiovascular-symptoms immediately (less than $30 \mathrm{~min}$ ) occurring after a glass of cow's milk (CM) were excluded of the study group. Patients with food protein-induced enterocolitis syndrome (FPIES) were also excluded A diagnosis of celiac disease by and a diagnosis of lactose intolerance were also considered as exclusion criteria. Two different groups of subjects were used as control groups, both with markedly different clinical features (a healthy control group without GI CMP reactions and a CMP anaphylaxis) were compared to the study group.

Skin prick tests (SPT) with commercial extracts of CMP were performed (IPI; Stallergenes, Spain). Measurement of the total concentration of IgE (tgE) in each serum was obtained by enzime-immunoassay (ImmunoCAP, Phadia AB, Uppsala, Sweden). Specific IgE (sIgE) against whole CM, CAS, ALA and BLG were also measured by the (ImmunoCAP) with a detection limit of 0.1 $\mathrm{kIU} / \mathrm{L}$. All patients experienced an open challenge test with cow's milk. Celiac disease and lactose intolerance was ruled out by absence of IgA anti-transglutaminase antibodies [6] by enzyme-linked immunoassay (EliA Celikey IgA, Phadia AB, Uppsala, Sweden) and by hydrogen breath test, respectively. The protocol was approved by the Regional Ethics Committee. Statistical analysis considered significant differences when $\mathrm{p} \leq 0.05$ (MannWhitney U test and Kruskall-Wallis test).

\section{Results}

A total of 336 subjects referring food reactions, out of 1344 pediatric patients were seen in the Outpatient Office during the 12-months study period. Thirty nine subjects (11\%) referred gastrointestinal symptoms exclusively -no other complain at least $30 \mathrm{~min}$ after CM consumption- and showed at least a positive sIgE to CMP. Median of age was 5 years-o and $55 \%$ were girls. The most prevalent symptom was abdominal cramps in 35 patients (90\%), followed by discomfort or abdominal distention in 30 patients (75\%), diarrhea in 10 patients (25\%) and constipation in 5 patients (12\%).

SPT with commercial extracts to CMP were positive in only $40 \%$ (16 patients). IgA anti-transglutaminase antibodies were absent in all patients [6]. Average of tgE on this group was $288 \mathrm{UI} / \mathrm{ml}$ (median $144 \mathrm{UI} / \mathrm{ml}$ ), while sIgE against BLG was dominant among the CMP sIgE profile with an average of $4.14 \mathrm{kU} / \mathrm{l}$ (median $1.67 \mathrm{kU} / \mathrm{l}$; range $0,21-33$ ) (Table 1 ). The other two proteins detected were casein, which is the dominant protein in systemic anaphylaxis [7] with an average of $1.74 \mathrm{kU} / \mathrm{l}$ (median $0.18 \mathrm{kU} / \mathrm{l}$ ) and another whey protein, ALA, with average of $0.83 \mathrm{kU} / \mathrm{l}$ (median $0.23 \mathrm{kU} / \mathrm{l})$. Average of sIgE levels to $\mathrm{CM}$ were $0.78 \mathrm{kU} / \mathrm{l}$ (median $0.27 \mathrm{kU} / \mathrm{l}$ ). The quotient sIgE casein/sIgE BLG in this selected population was always lower than 1 (average 0.3). The healthy control group without GI CMP reactions had levels of $\operatorname{sgE}<0.1 \mathrm{kU} / 1$ with every single CM protein.

All patients experienced a clinical improvement of their symptoms after the implementation of CM free diet. The clinical improvement was defined as that gastrointestinal discomfort referred in history was completely yield. A new open challenge with a glass of CM reproduced the initial symptoms in all patients. A subsequent open oral challenge with dairy products (one yogurt) was well tolerated in all patients. Additionally these patients maintained taking dairy products on a daily basis diet (fermented such as yogurt or cheese, and baked such as custard).

\section{Discussion}

Bovine BLG, the major whey protein of cow's milk $(\sim 3 \mathrm{~g} / \mathrm{l})$, is a small protein, with an $18.4 \mathrm{kDa}$ molecular weight. Unlike the other main whey protein, no clear function has been identified to $\beta$-lactalbumin, although a role in the transport of some hydrophobic molecules [8] has been suggested. Among bovine whey proteins, BLG is also a known prevalent allergen, as listed in Annex IIIa of Directive 2000/13/EC and demonstrated by both SPT and oral challenges [9].

The patients with the phenotype of GI allergy have shown low, but positive levels of sIgE against BLG. Patients with this specific phenotype are not susceptible to follow regular CMP desensitization protocols [7, 10], which it has been a hot topic in recent years. The current CMP desensitization protocols have been specifically designed for those patients with the classical anaphylaxis phenotype of IgE-mediated reactions [7], although no guidelines have been developed to determine whose patients may benefit. Interestingly, the quotient sIgE CAS/sIgE BLG in the patients with the GI allergy phenotype was always lower than 1 (average 0.3) compared to those subjects with anaphylaxis, with a quotient higher than 1 [7], given that their dominant allergenic CP is casein (Table 1).

Remarkably 10 patients had levels of sIgE against CM lower than $0.1 \mathrm{kU} / \mathrm{l}$ and additionally 12 more subjects 
Table 1 Figures of levels of specific IgE against some cow's milk protein fractions in the G-I group and Anaphylaxis group

\begin{tabular}{|c|c|c|c|c|c|c|c|}
\hline & \multicolumn{3}{|c|}{ Gl allergy $n=39$} & \multicolumn{3}{|c|}{ Anaphylaxis $n=20$} & \multirow{2}{*}{$\begin{array}{l}\text { Significance } \\
\text { p }\end{array}$} \\
\hline & Average & Range & Median & Average & Range & Median & \\
\hline Total lgE (IU/ml) & 288 & $16-2360$ & 144 & 457 & $295-2500$ & 360 & $<0.01$ \\
\hline \multicolumn{8}{|l|}{ Allergen specific lgE (kU/l) } \\
\hline Whole cow's milk & 0.74 & $0-2.48$ & 0.26 & 189 & $30-586$ & 146 & $<0.01$ \\
\hline Casein & 1.74 & $0-4.8$ & 0.18 & 178 & $26-544$ & 90 & $<0.01$ \\
\hline a-lactoalbumin & 0.83 & $0-3.7$ & 0.23 & 21 & $9-34$ & 21 & $<0.01$ \\
\hline$\beta$-lactoglobulin & 4.14 & $0.10-33.4$ & 1.67 & 16.2 & $2.1-38$ & 7.25 & $<0.01$ \\
\hline Ratio casein/ $\beta$-lactoglobulin & 0.30 & $0.08-0.99$ & 0.22 & 20 & $2.1-99$ & 9.5 & $<0.01$ \\
\hline
\end{tabular}

showed levels between 0.1 and $0.35 \mathrm{kU} / \mathrm{l}$, which has been the traditional cutoff of many immunoassays of specific IgE. This data is interesting, since many of these patients, with sIgE to CM lower than $0.35 \mathrm{kU} / 1$ may be under-diagnosed in the past. The current limit of detection, as low as $0.1 \mathrm{kU} / \mathrm{l}$, for sIgE might help to discriminate among different clinical profiles [11] of allergy. Similarly, ten patients with levels of sIgE against CM lower than $0.1 \mathrm{kU} / \mathrm{l}$, had levels of sIgE to BLG higher than $0.1 \mathrm{kU} / \mathrm{l}$. With these findings, we believe that the determination of several proteins including CAS, ALA and BLG, in addition to specific IgE to CM, should be mandatory. The new detection limits of $0.1 \mathrm{kU} / 1$ should always be also recommended. It was only noticed that in these subjects with this phenotype of patients, the sensitivity of sIgE quite higher than the SPT with commercial CM extracts, detecting only $40 \%$ of patients with a positive SPT.

A diet including dairy products but free of CM has been useful with strong positive consequences in their nutrition. Dairy products are those obtained by fermentation of cow milk as yogurt. Just as it has been shown that heat diminishes the reactivity of milk $[12,13]$ or egg [14], fermentation some dairy products may help to decrease some proteins. In the yogurts it has been shown BLG detection greatly diminished compared to fresh milk measured by chromatography [15]. Even many yogurts have shown an absence of BLG; while other proteins such as CAS and ALA remain present in these yogurts. It is not known the cause why this happens. This could be argued because processing of dairy products could stimulate polymerization of BLG, which is the major whey protein of cow's milk, in tetramers that probably changes spatial distribution of allergen epitopes [12] and decreasing allergenicity in children and adults with an IgE-mediated cow's milk allergy [16]. Since there are differences between different products [12], it would also be necessary that manufacturers prove the presence or absence of BLG in natural form to unsure their labeling convinces the requirements to identify BLG in food products. Further studies should be performed to delineate this GI allergy phenotype and if it is suitable to maintain dairy products in these patients. More studies are necessary in defining all possible different milk allergy phenotypes.

\section{Abbreviations}

IgE: immunoglobulin E; Gl allergy: gastrointestinal food allergy; slgE: specific IgE; tlgE: total lgE; CM: whole cow's milk; CMP: cow's milk proteins; CAS: casein; ALA: a-lactoalbumin; BLG: $\beta$-lactoglobulin; SPT: skin prick tests.

\section{Authors' contributions}

PPG was the main researcher in the fieldwork performing the desensitization in the Paediatric Intensive Care Unit. YB was the main researcher in the lab performing all the immunoassays and assessing the results. ISM and RG collaborated in the original idea, helped in recruiting data, performed all the in vitro study by immunassays and discussed the final version of the manuscript. AF assisted in the lab performing immunoassays and assessing the results. VM is the principal senior investigator, had the original idea, asked for internal funding and wrote the final version of the manuscript. All authors have actively discussed and approved the final version of the manuscript. All authors read and approved the final manuscript.

\section{Author details}

${ }^{1}$ Consulta de Alergia Infantil, Unidad de Alergología-Norte, Hospital del Tórax/ Ofra, CHUNSC, Sta. Cruz de Tenerife 38320, Spain. ${ }^{2}$ Immunology, Hospital Universitario de Canarias, La Laguna, Spain. ${ }^{3}$ Unidad Alergología-Norte, Hospital Tórax, CHUNSC, Sta Cruz de Tenerife, Spain.

\section{Acknowledgments}

We would like to thank to all registered nurse and lab technician involved in this study.

\section{Ethics committee approval}

Compilation of data was recorded following European standards of data protection and study was approved by the Clinical Research Ethics Committee of the Region (HUNSC: P.I-35/11 and 24/14).

\section{Competing interests}

All authors declare that they have no competing interests.

\section{Role of funding source}

Authors declare that the source of funding has been the internal Funding of Unidad de Gestión Alergología-Norte, Hospital del Tórax/Ofra.

Received: 13 September 2015 Accepted: 4 January 2016

Published online: 23 February 2016 


\section{References}

1. Morita H, Nomura I, Matsuda A, Saito H, Matsumoto K. Gastrointestinal food allergy in infants. Allergol Int. 2013;62:297-307.

2. lacono G, Cavataio F, Montalto G, Soresi M, Notarbartolo A, Carroccio A. Persistent cow's milk protein intolerance in infants: the changing faces of the same disease. Clin Exp Allergy. 1998;28:817-23.

3. Wang J, Lin J, Bardina L, et al. Correlation of lgE/lgG4 milk epitopes and affinity of milk-specific lgE antibodies with different phenotypes of clinical milk allergy. J Allergy Clin Immunol. 2010;125(695-702):e1-6.

4. Iacono G, Cavataio F, Montalto G, et al. Intolerance of cow's milk and chronic constipation in children. N Engl J Med. 1998;339:1100-4.

5. Crowley ET, Williams LT, Roberts TK, Dunstan RH, Jones PD. Does milk cause constipation? A crossover dietary trial. Nutrients. 2013;5:253-66.

6. Barrios Y, Poza-Guedes P, Sanchez-Machin I, et al. IP-10 in pediatric celiac disease and food allergy. Am J Gastroenterol. 2014;109:1085-6.

7. Poza P, Glez R, Barrios Y, Franco A, Matheu V. MIP-1a, MCP-1, and desensitization in anaphylaxis from cow's milk. N Engl J Med. 2012;367:282-4

8. Kontopidis G, Holt C, Sawyer L. Invited review: $\beta$-lactoglobulin: binding properties, structure, and function. J Dairy Sci. 2004;87:785-96.

9. Costa AJ, Sarinho ES, Motta ME, Gomes PN, de Oliveira de Melo SM, da Silva GA. Allergy to cow's milk proteins: what contribution does hypersensitivity in skin tests have to this diagnosis? Pediatr Allergy Immunol. 2011;22:e133-8.
10. Poza-Guedes P, Barrios $Y$, Fuentes $V$, et al. Downregulation of angiogenesis factors, VEGF and PDGF, after rapid IgE desensitization and oral immunotherapy in children with food allergy. Biomed Res Int. 2014;2014:372567.

11. Caubet JC, Ford LS, Sickles $L$, et al. Clinical features and resolution of food protein-induced enterocolitis syndrome: 10-year experience. J Allergy Clin Immunol. 2014;134:382-9.

12. Ehn BM, Ekstrand B, Bengtsson U, Ahlstedt S. Modification of lgE binding during heat processing of the cow's milk allergen $\beta$-lactoglobulin. J Agric Food Chem. 2004;52:1398-403.

13. Nowak-Wegrzyn A, Bloom KA, Sicherer SH, et al. Tolerance to extensively heated milk in children with cow's milk allergy. J Allergy Clin Immunol. 2008;122:342-7-347 (e1-2)

14. Lemon-Mule H, Sampson HA, Sicherer SH, Shreffler WG, Noone S, NowakWegrzyn A. Immunologic changes in children with egg allergy ingesting extensively heated egg. J Allergy Clin Immunol. 2008;122(977-83):e1.

15. Ruprichovà L, Drackovà M, Borkovcocà I, Vorlovà L. Determination of proteins in yoghurt. J Microbiol Biotechnol Food Sci. 2012;1:644-50.

16. Olivier CE, Lima RP, Pinto DG, et al. In search of a tolerance-induction strategy for cow's milk allergies: significant reduction of $\beta$-lactoglobulin allergenicity via transglutaminase/cysteine polymerization. Clinics (Sao Paulo). 2012;67:1171-9.

\section{Submit your next manuscript to BioMed Central and we will help you at every step:}

- We accept pre-submission inquiries

- Our selector tool helps you to find the most relevant journal

- We provide round the clock customer support

- Convenient online submission

- Thorough peer review

- Inclusion in PubMed and all major indexing services

- Maximum visibility for your research

Submit your manuscript at www.biomedcentral.com/submit
() Biomed Central 